Poznańskie Studia Teologiczne 28(2014), s. 177-194.

doi: $10.14746 /$ pst.2014.28.12

Maria Miduch

Wyższe Seminarium Duchowne Towarzystwa Salezjańskiego

Kraków

\title{
Miejsce pogan w rzeczywistości eschatologicznej apokalips żydowskich powstałych pomiędzy rokiem 70 a 132 po Chr.
}

\section{Apokaliptyka jako szczególny rodzaj literacki}

Studia nad apokaliptyka, jako wytworem literackim określonego środowiska, pozwalają dostrzec pewną zależność pomiędzy sytuacją polityczną, społeczną i religijną danej grupy a jej predylekcją do rodzaju literackiego. Źródeł apokaliptyki bowiem należy szukać w środowisku Żydów uprowadzonych do Babilonii ${ }^{1}$. Skomplikowana rzeczywistość, jaka stała się udziałem przesiedleńców, musiała wywrzeć wpływ na duchowość i sposób jej wyrażania. Brak świątyni, oderwanie od ojczyzny, poczucie osamotnienia i opuszczenia przez Boga zaowocowało chęcią poszukiwania z Nim kontaktu innymi niż do tej pory drogami. Nie bez znaczenia pozostaje tu także spotkanie z pogańską kulturą Babilonu. Pociaga ona zagubionych w nowym świecie Żydów, w ich oczach staje się atrakcyjna, choćby dzięki „triumfowi” bóstw babilońskich nad nimi w akcie uprowadzenia i przejęcia panowania. Na wygnaniu, z dala od ruin świątyni rodzi się więc żydowska apokaliptyka: przesycona tęsknotą za bliskością z Bogiem i chęcią ukazania szczególnej więzi, jaką ma Pan ze swoim narodem, który daje mu wskazania i nie opuszcza go nawet na obczyźnie.

Jak sama grecka nazwa wskazuje, apokalipsa jest zapisem objawienia, odsłonięcia prawd zakrytych przed większością ludzi. Odnosi to czytelnika do tajemniczej sfery, która wymaga poznania, odsłonięcia ze względu na dobro duchowe odbiorców. Stąd też niektórzy badacze tematu starają się połączyć ruch apokaliptyczny z nurtem mądrościowym, negując jednocześnie jego prorockie korzenie $^{2}$. Nie da się jednak zaprzeczyć mocnemu powiązaniu profetyzmu i apokaliptycyzmu. Zaobserwować można to na przykładzie ksiagg, które weszły w kanon Pisma Świętego a w swojej formie wyraźnie czerpią z apokaliptyki³.

\footnotetext{
${ }^{1}$ Por. P. Sacchi, L' apocalittica giudaica e la sua storia, Brescia 1999, s. 10.

2 Por. S. Jędrzejewski, Apokaliptyka jako rodzaj literacki, „Ruch Biblijny i Liturgiczny” 51(1998) 1, s. 29-31.

${ }_{3}^{3}$ Por. M. Parchem, Księga Daniela, Częstochowa 2008, s. 76-80.
} 
Apokalipsa jako odrębny gatunek literacki rządzi się własnymi prawami. Podporządkowała sobie język, środki stylistyczne i tematy teologiczne. W sposób bardzo obrazowy stara się przedstawić niewyrażalną boską rzeczywistość. Stąd pełna jest symboli, porównań i odniesień do wyobraźni czytelnika. Jednak w miejscu tym należy zaznaczyć, że autorzy tych dzieł nigdy nie stawiali sobie za zadanie całkowitego odkrycia tajemnicy, a jedynie przybliżenie do niej na tyle, na ile sam objawiający pozwalał.

Posługując się wizją oraz snem, apokalipsa rozbudowała świat pośredników, którzy pomagają w przyjęciu Bożego objawienia. Angelologia, a co za tym idzie, i demonologia stały się narzędziami do przekazania nadprzyrodzonych wizji ${ }^{4}$. Szczególne miejsce w swoim teologicznym przesłaniu apokaliptyka poświęca eschatologii. Tematy związane z tym, co ostateczne, znajdują się w szczególnym zainteresowaniu apokaliptyków. Niewątpliwie miała na to wpływ sytuacja polityczno-społeczna, która leżała u podstaw wyboru przez autorów właśnie apokaliptyki do przekazania swoich przemyśleń. Kryzys przesiedlenia babilońskiego popchnął autorów omawianego typu pism w stronę nadziei wyrażonej w formie Bożego objawienia. Wizje, sny, których zapisem stają się apokalipsy, mają na celu pocieszenie narodu, wzbudzenie w nim ducha wiary w wierność Bożych obietnic.

Nic więc dziwnego, że tak traumatyczny moment jak zburzenie świątyni Jerozolimskiej w roku 70 po Chr. zaowocował powstaniem czterech żydowskich apokalips, których treść odnosiła się do tego smutnego wydarzenia, a jednocześnie wybiegały w przyszłość, wskazując na coraz bliższy koniec. Inwazja okupanta i obrócenie $\mathrm{w}$ gruzy religijnego centrum żydowskiego świata $\mathrm{w}$ znaczący sposób zaważyły na losach judaizmu i jego wyznawców. Zburzenie świątyni jerozolimskiej było niewątpliwie traumą dla Żydów. Jednak wydarzenia sprzed wielu lat zakończone deportacją do Babilonii, a później powrotem z niej, w pewien sposób przygotowały do przyjęcia ciosu zadanego przez Tytusa. Żydzi wykształcili struktury synagogalne, które pomagały im zachować tożsamość, a także mieli w pamięci przejściowość okresu bezświątynnego. Niemniej jednak czas rzymskiej okupacji, prześladowań był porównywalny z nieszczęściem, jakim była dominacja Babilonu. Nie wydają się więc przypadkowe częste odwołania do czasów babilońskich, na jakie możemy trafić w apokalipsach powstałych pomiędzy rokiem 70 a 132 po Chr. Dwie z czterech apokalips napisanych w tym właśnie przedziale czasowym w sposób bezpośredni odwołują się do zburzenia świątyni przez Nabuchodonozora. Zarówno IV Księga Ezdrasza, jak i II Księga Barucha, poprzez swoją koncepcję literacką odnoszą czytelnika bezpośrednio do tych czasów, stosując popularny w literaturze apokryficznej zabieg podszycia się pod

${ }^{4} \mathrm{O}$ rozbudowanej angelologii żydowskich apokalips szerzej: S. Jędrzejewski, Angelologia Etiopskiej Księgi Henocha (Henet), „Ruch Biblijny i Liturgiczny” 3(2006), s. 203-218. 
wielkie postacie minionej epoki5. Ezdrasz i Baruch, dwie wielkie figury związane $\mathrm{z}$ trudnym okresem babilońskim, stają się przewodnikami dla zgnębionych rzymskimi rządami Żydów.

\section{Apokalipsy żydowskie powstałe pomiędzy rokiem 70 a 132 po Chr.}

Literatura żydowska powstała $\mathrm{w}$ okresie pomiędzy zburzeniem świątyni przez Tytusa a wybuchem powstania Bar Kochby, mimo iż jest skarbnicą wiedzy na temat starożytnego judaizmu, nie cieszy się wielkim zainteresowaniem badaczy - tak na gruncie polskim, jak i zagranicznym. Cztery powstałe w tym czasie apokalipsy doczekały się co prawda wydań krytycznych wraz z komentarzami, lecz nie podjęto próby analizy porównawczej owych tekstów ${ }^{6}$. Tylko nieliczne wątki teologiczne zawarte w owych tekstach opracowano, poświęcając im osobne publikacje ${ }^{7}$. Próba teologicznego przedstawienia miejsca narodów pogańskich w apokalipsach powstałych pomiędzy rokiem 70 a 132 po Chr. wydaje się głęboko uzasadniona ze względu na brak opracowań na ten temat.

IV Księga Ezdrasza nie jest jedyną księgą apokryficzną, która odwołuje się do postaci wielkiego reformatora Ezdrasza. Jego osoba na tyle silnie wrosła w kształtujący się co dopiero judaizm, że stał się on bohaterem wielu dzieł ${ }^{8}$. Księga, o której mowa w niniejszym opracowaniu, to tak zwana apokalipsa palestyńska, skoncentrowana na nadziei odbudowy narodu Izraela. Podstawą do ufności w przyszłe odrodzenie są tu obietnice, jakie Bóg złożył w swoim narodzie. Wybiega ona w przyszłość, pokazując to, co ma nastapić, co musi się stać, by ukazała się wierność Boga względem przymierza. Już samo porównanie sytuacji Żydów z okresu babilońskiego do sytuacji z roku 70, poprzez usytuowanie apo-

\footnotetext{
${ }^{5}$ Por. S. Jędrzejewski, U korzeni zła, Lublin 1997, s. 59-60.

${ }^{6}$ Wydania krytyczne apokalips, z których korzystano w niniejszym opracowaniu, to: The Ezra Apocalypse, 4 Ezra, G.H. Box (ed.), London 1912; The Rules of Tyconius, The Forth Book of Ezra, Euthaliana, w: J. Armitagr Robinson (ed.), Text and Studies, Contribution to Biblical and Patristic Literature, vol. 7, Cambridge 1895; Liber Apocalypseos Baruch Filii Neriae, translatus de greco in syriacum et Epistola Baruch Filii Neriae, M. Kmosko (ed.), Paris 1907; L'apocalypse d'Abraham, en vieux slave, introduction, texte critique, tradition et commentaire, R. Rubinkiewicz (red.), Lublin 1987; Oracula Sibillina, C. Alexandre (ed.), Paris 1869.

${ }^{7}$ Przykładem może być: N. Rivka, The Destruction of Jerusalem and the Idea of Redemption in Syriac Apocalypse of Baruch, Leiden-Boston, 2003; M.E. Stone, Feature of the Eschatology of IV Ezra, Atlanta 1989; E.M. Humphrey, Ladies and the Cities, Transformation and Apocalyptic Identity in Joseph and Aseneth, 4 Ezra, The Apocalypse and Shepherd of Hermas, Sheffield 1995; J.J. Collins, The Palce of the Fourth Sybil in the Development of Jewish Sibyllina, ,Journal of Jewish Studies" 25(1974), s. 365-380.

${ }^{8}$ Por. J.C. VanderKam, Wprowadzenie do wczesnego judaizmu, Warszawa 2006, s. 61; K. Pilarczyk, Literatura żydowska od epoki biblijnej do haskali. Wprowadzenie religioznawcze, literackie $i$ historyczne, Kraków 2006, s. 157-159; S. Mędala, Wprowadzenie do literatury międzytestamentalnej, Kraków 1994, s. 152-153.
} 
kalipsy w czasie działań Nabuchodonozora, staje się dla czytelników źródłem nadziei. Struktura literacka księgi prawdopodobnie nie jest przypadkowa. Możemy wskazać na siedem elementów podstawowych wchodzących w skład dzieła. Proponuje się jego dwojaki podział: $3+1+3$ lub $3+3+1$. Ważną cechą księgi jest jej dialogiczny charakter. Autor apokalipsy, utożsamiając się z Ezdraszem, zadaje Bogu szereg pytań, przez co staje się głosem całego narodu. W swoim dialogu z Bogiem zawiera troski, obawy i nadzieje całego ludu, który został zmiażdżony jerozolimskimi wydarzeniami roku 70. W jego podejściu do otaczającej go rzeczywistości niektórzy doszukują się tradycji mądrościowej”.

Pierwsza z sekcji rozpoczynających księgę składa się z modlitwy Ezdrasza zwanego tu Salatielem oraz Bożej odpowiedzi na nią udzielonej poprzez anioła Uriela. Ezdrasz wyrzuca Bogu niesprawiedliwość, wyrażoną w nieszczęściach, jakie spadły na Naród Wybrany. Odpowiedzią Uriela jest przywołanie historii grzechu, który wszedł na świat przez pierwszych rodziców. Nakazuje on także Ezdraszowi mieć na uwadze nieodgadnione plany Boga. „Nie wybiegaj myślą ponad Najwyższego!" (4 Ezd 4,34), upomina go.

W kolejnej części księgi poruszony został problem wybrania. Boży posłaniec - Uriel, cierpliwie przypomina o niezgłębionej Bożej mądrości oraz o miłości Boga do swojego ludu. Mówi także o rzeczach, które mają się dopiero wydarzyć, i o ich znaczeniu.

Schemat sekcji trzeciej przypomina schemat zastosowany w dwóch ją poprzedzających. Ezdrasz woła do Boga i otrzymuje odpowiedź poprzez Uriela. Ten zapowiada mu ukazanie się oblubienicy pod postacią miasta. W tekście czytamy: „Ukaże się bowiem oblubienica objawiająca się jako miasto” (4 Ezd 7,26b). Anielski przewodnik zwiastuje także nadejście Mesjasza (por. 4 Ezd 7,28). W części tej znajdujemy także zapowiedź sądu, jaki ma nadejść.

Środkowa z omawianych sekcji łączy pierwszą i drugą część IV Księgi Ezdrasza. Stanowi ją tak zwana „wizja płaczącej niewiasty”. Badacze uznają ten obraz za pierwszą dającą nadzieję wizję Księgi ${ }^{10}$.

Sekcja piąta to sen Ezdrasza opowiadający o wrogich mocarstwach. To właśnie w tej wizji egzegeci dopatrują się odwołania do czasów okupacji rzymskiej. Trójgłowy orzeł jest więc symbolem następujących po sobie cesarzy: Wespazjana, Tytusa i Domicjana ${ }^{11}$. W tej wizji zostaje także przywołany Mesjasz. Ukryty jest on pod symbolem lwa, który przeciwstawia się wrogiej sile ostatniego z królestw. On też staje się pocieszycielem Izraela.

${ }^{9}$ G.W.E. Nickelsburg, Jewish Literature between the Bible and the Mishna, Minneapolis 2005, s. 27.

${ }^{10}$ Por. E.M. Humphrey, Ladies and the Cities, Transformation and Apocalyptic Identity in Joseph and Aseneth, 4 Ezra, The Apocalypse and Shepherd of Hermas, Sheffield 1995, s. 58.

${ }^{11}$ Por. The Apocrypha and Pseudoepigrapha of the Old Testament, vol. 2, R.H. Charles (ed.), Oxford 1969, s. 552. 
Kolejna z sekcji księgi skoncentrowana jest wokół obrazu człowieka wychodzącego z morza, który także jest figurą mesjańską.

Sekcja zamykająca księgę to polecenie Uriela mówiące o konieczności podyktowania tekstów pisarzom. Część z nich to księgi kanoniczne Biblii Hebrajskiej $^{12}$, a część to tajemne objawienie przeznaczone dla wybranych.

Podobną siedmioczęściową strukturę ma II Księga Barucha, zwana także Syryjska Księga Barucha. Jej treść jest opisem wizji odnoszących się do zburzenia Jerozolimy, które według narratora ma nastąpić w najbliższej przyszłości. Dzieło zniszczenia nie wyjdzie jednak spod ręki najeźdźcy. Wolą Bożą jest destrukcja świątyni. Najwyższy pośle więc swoich aniołów, by wykonali Jego rozkaz. W ten sposób najświętsze miejsce na ziemi nie zostanie zbezczeszczone przez pogan. Księga porusza również temat zbliżającego się końca i zapowiadających go znaków. Rzeczywistość eschatologiczna jest tu powiązana z ideą mesjańskiego królestwa i panowania Pomazańca. Także i tutaj czytelnik może napotkać charakterystyczną dla apokalipsy formę przekazu, jaką są wizje. Obraz winnicy i lasu oraz wód czystych i brudnych to doskonałe tego przykłady. Periodyzacja historii, z jaką można się tu spotkać, to kolejny rys literatury apokaliptycznej ${ }^{13}$. W całej księdze przewija się motyw nadziei na nową Jerozolimę, nową świątynię.

Niektórzy z badaczy wskazują na pewne chrześcijańskie interpolacje znajdujące się w tekście księgi. Jednak zwykło się je uważać za dodatek późniejszych redaktorów niemający większego wpływu na ortodoksyjnożydowski tekst ${ }^{14}$. W autorze tekstu niektórzy z badaczy są skłonni nawet widzieć samego rabbiego Akibę $e^{15}$. Nie jest to do końca uzasadnione, niewątpliwie jednak sam autor uważa się za spadkobiercę myśli proroka Jeremiasza ${ }^{16}$ i pretenduje jednocześnie do roli drugiego Mojżesza ${ }^{17}$.

Kolejną księgą apokaliptyczną, powstałą w środowisku żydowskim pomiędzy rokiem 70 a 132, jest Apokalipsa Abrahama. Choć w samym tekście księgi możemy dostrzec warstwy, które wskazują na okres wcześniejszy niż I wiek po Chr., to całość jednak została skomponowana przez redaktora-apokaliptyka ok. 80 roku po $\mathrm{Chr}^{18}$ Do naszych czasów zachowała się ona w przekładzie staro-cerkiewno-słowiańskim, który to z kolei jest przekładem z tekstu greckiego. Nie

\footnotetext{
${ }^{12}$ Pisownia terminu wskazuje na odwołanie się do kanonu świętych pism judaizmu rabinicznego.

${ }^{13}$ Por. J.E. Wright, Baruch Ben Neriah. From Biblical Scribe to the Apocalyptic Seer, South Carolina 2003, s. 84.

${ }^{14}$ Por. N. Rivka, The Destruction..., dz. cyt., s. 5.

${ }^{15}$ Por. G.H.M. Box, The Ezra-apocalypse, dz. cyt., s. lxviii.

${ }^{16}$ Por. J.E. Wright, Baruch Ben Neriah..., dz. cyt., s. 97.

${ }^{17}$ Tamże, s. 92

${ }^{18}$ Por. The Apocalypse of Abraham (with a translation from the Slovanic text and notes), G.M.H. Box (ed.), London 1919, s. XV-XVI.
} 
był to jednak język oryginału, w tekście znajdują się bowiem liczne hebraizmy i arameizmy, które wskazują na semicką wersję księgi ${ }^{19}$.

Jej przesłanie koncentruje się wokół przymierza Boga z narodem Izraela. Jest ono obecne w obu zasadniczych częściach apokalipsy. Pierwsza z nich ma na celu wprowadzenie czytelnika w tradycję Abrahama i zaznaczenie pewnych wątków teologicznych rozwijanych później w części typowo apokaliptycznej. W haggadycznej części księgi niektórzy badacze dopatrują się ukrytej historii sądu zarówno nad politeistami, jak i nad mocarstwami, których nazwy kryją w sobie pogańskie bóstwa występujące $\mathrm{w}$ owej historii ${ }^{20}$. Podczas niebiańskiej podróży zostały Abrahamowi objawione zarówno tajemnice niebiańskie, jak i ziemskie, dotyczące ludzkiej historii ${ }^{21}$. Nie podróżuje on jednak sam - został mu przydzielony niebiański przewodnik Jaoel. To on poucza patriarchę, jak przygotować się do spotkania z Najwyższym i jak zachować się w Jego obecności. Anioł tłumaczy także Abrahamowi kluczowe momenty ziemskiej historii, które dane jest im oglądać.

IV Księga sybilińska zajmuje szczególne miejsce pośród apokalips żydowskich powstałych po zburzeniu świątyni. Miejscem jej powstania było środowisko diaspory greckiej. O jej wyjątkowości stanowi pogański korzeń dzieła. Tradycja sybilińska była bowiem ściśle połączona z kręgiem kultury greckiej i rzymskiej ${ }^{22}$. Jednak przepowiednie wieszczki zwanej Sybillą zyskały wielką popularność i krąg wiernych słuchaczy nie tylko w świecie pogańskim ${ }^{23}$. Żydowski autor zafascynowany fenomenem legendarnej prorokini postanowił wykorzystać ją do dobrego celu. Przybierając jej imię, stał się orędownikiem wiary w jedynego Boga.

IV Księga sybilińska, zgodnie z utartą tradycją sybilińską, przyjmuje formę mowy prorockiej. Jest to zabieg literacki bardzo popularny na starożytnym Bliskim Wschodzie ${ }^{24}$. Narrator, utożsamiając się z Sybillą, występuje tu jako wieszcz jedynego, prawdziwego Boga. Jego pouczenie i przepowiednie koncentrują się wokół wezwania do nawrócenia, odejścia od bezbożności, nieprawości i przewrotności. Przywołane wydarzenia z historii powszechnej stały się dla autora okazją do ukazania pleniącego się w świecie zła.

${ }^{19}$ Por. A. Rubenstein, Hebraisms in the Apocalypse of Abraham, „Journal of Jewish Studies” 2(1954), s. 132-135.

${ }^{20}$ Por. R. Rubinkiewicz, Apokalipsa Abrahama 1-6. Propozycje interpretacji symbolicznej, „Roczniki Teologiczno-Kanoniczne” 29, 1(1982), s. 79-94.

${ }^{21}$ Por. Pisma apokaliptyczne i testamenty, M. Parchem (red.), Kraków 2010, s. 70-71.

${ }^{22}$ Por. J.R. Barlett, Jews in the Hellenistic World, Josephus, Aristeas, The Sibylline Oracles, Eupolemus, Cambridge 1985, s. 35.

${ }^{23}$ Poprzez kulturę żydowską Księga sybilińska dotarła do świata chrześcjańskiego. Znane są tzw. Chrześcijańskie wyrocznie Sybilli. Mowa tu o Księdze VII i VIII sybilińskiej. Por. Pisma..., dz. cyt., M. Parchem (red.), s. 89.

${ }^{24}$ Por. J.J. Collins, The Sybylline Oracles, w: M. Stone (red.), Jewish Writings of Second Temple Period, Assen-Philadelphia 1984, s. 357. 


\section{Apokaliptyka w służbie teologii - koncepcje eschatologiczne}

Mimo wspólnego przedziału czasowego, w jakim powstały prezentowane apokalipsy, oraz wspólnego im gatunku literackiego są to dzieła różne, prezentujące różnorodne koncepcje teologiczne. Nie bez znaczenia pozostaje tu środowisko, w jakim żyła dana, przejawiająca apokaliptyczne sympatie, wspólnota. Każdy z autorów/redaktorów trochę inaczej spogląda w przyszłość i inaczej postrzega Bożą interwencję. Nie można oczekiwać, by z tak różnorodnych dzieł wyłoniła się jedna spójna koncepcja eschatologiczna. Nie można także oczekiwać jednego poglądu na miejsce pogan w ostatecznej rzeczywistości.

Analiza tekstów ksiąg pozwala na wyłonienie pięciu podstawowych koncepcji eschatologicznych. Ukazuje to różnorodność, jaką niósł w sobie ówczesny judaizm, oraz bogactwo refleksji teologicznej wypływającej z traumatycznych doświadczeń rzymskiej okupacji. W koncepcjach eschatologicznych, wyłonionych z myśli teologicznej apokalips, miejsce znalazły także narody pogańskie. Temat ten dla autorów apokalips zapewne miał szczególne znaczenie, wszak są to dzieła będące owocem egzystencji wśród obcych ludów: czy to w ojczyźnie znajdującej się pod okupacją rzymską, czy też w diasporze.

\subsection{Eschatologia nacjonalistyczna}

Pierwszą koncepcję wydobytą $\mathrm{z}$ analizowanych tekstów można nazwać eschatologią nacjonalistyczną. Zaznacza się w niej bardzo wyraźnie wpływ aktualnej apokalipsom sytuacji politycznej. Krytyczna sytuacja, w jakiej znalazł się Naród Wybrany, wymaga od niego odpowiedzi na pytanie o jego tożsamość. Do tej pory była przecież ona kształtowana na podstawie scentralizowanego kultu $\mathrm{w}$ świętym mieście ${ }^{25}$. Trzy $\mathrm{z}$ omawianych pism apokaliptycznych odwołują się do problemu, jakim jest żydowska tożsamość. IV Księga Ezdrasza, II Księga Barucha oraz Apokalipsa Abrahama w obliczu nieszczęść, jakie nawiedziły naród Izraela, stara się przypomnieć o Bożej wierności względem dokonanego wyboru, a tym samym podtrzymuje lud w ufności względem Najwyższego. Autorzy poszczególnych tekstów w różny sposób zapatrują się na kwestie związane z wybraństwem narodu, jednak każdy z nich przyznaje mu wyjątkowe miejsce $\mathrm{w}$ eschatologicznej teologii, jaką prezentują. Izrael jest tym, który poprzez Bożą decyzję odróżnia się od pogan go otaczających. W sposób szczególny rzuca się w oczy czytelnikowi owa ,izraelocentryczność” przesłania omawianych apokalips. Izrael staje się punktem odniesienia dla wydarzeń historycznych przywołanych na kartach ksiag oraz dla teologii przedstawianej przez autorów. On jest odbiorcą Bożego orędzia, tylko on może patrzeć w przyszłość z nadzieją.

${ }^{25}$ Por. H. Witczyk, Narodziny i dzieje państwa w dawnym Izraelu, w: G. Witaszek (red.), Życie spoleczne w Biblii, Lublin 1997, s. 97-100. 
Wybawienie, jakiego oczekuje, będzie kolejnym elementem podkreślającym jego oddzielenie od innych narodów.

Pytania, które kieruje Ezdrasz do Boga, nie podają w wątpliwość Bożej miłości do Izraela, lecz raczej chcą odgadnąć motyw kary, jaka spadła na Żydów ${ }^{26}$. Boży wybór i Boże umiłowanie Izraela wielokrotnie zostały podkreślone w tekście IV Księgi Ezdrasza. Czytamy tam, że świat został utworzony właśnie ze względu na Naród Wybrany. „Ze względu na nich uczyniłem świat” (4 Ezd 7,10) powie Bóg do Ezdrasza. Wybór Żydów, który dokonał się przed wiekami, ma skutki na płaszczyźnie eschatologicznej ${ }^{27}$. Boża interwencja w losy świata jest przecież związana z Bożą wiernością wobec Izraela. Także w przyszłości nie straci on swojej pozycji względem innych narodów. On jeden pozostaje w szczególnej relacji względem swojego Obrońcy, jakim jest Bóg. Koncepcja eschatologicznego Mesjasza przedstawiona $\mathrm{w}$ księdze również nosi na sobie znamiona nacjonalistyczne. Pomazaniec, który pojawia się w wizji „orła i lwa” (por. 4 Ezd 11.12), pochodzi z rodu Dawida i jest obrońcą swoich rodaków. Występuje on przeciw poganom, którzy zadają ból Izraelowi. Podobnie przedstawia się koncepcja Mesjasza zaprezentowana w wizji „człowieka wychodzącego z morza” (por. 4 Ezd 13). Jawi się on jako ten, który będzie sądził narody pogańskie, a zgromadzi Izraela w bezpiecznej „granicy świętej” (por. 4 Ezd 13,48). Mesjańskie działania jeszcze bardziej podkreślają opozycję, w jakiej stają Żydzi do reszty świata. Działania Boże - także te podjęte przez Mesjasza - dokonują się ze względu na dobro Narodu Wybranego, a wymierzone sa przeciw narodom. Poganie ewidentnie jawią się tu jako element opresji, jakiej doświadcza Izrael.

Podobnie w II Księdze Barucha Naród Wybrany stał się ważnym elementem koncepcji eschatologicznej. Autor księgi ani przez chwilę nie wątpi o szczególnym miejscu Izraela w planach Bożych i jego wyjątkowym miejscu pośród innych narodów. Pojawiające się w tekście odwołania do prawa i Syjonu są przywołaniem mocno zakorzenionych w świadomości Żydów Bożych obietnic. Sa one jednocześnie wskazówką dla umieszczenia Narodu Wybranego w szczególnym miejscu nadchodzącej rzeczywistości eschatologicznej. To, co się dzieje i będzie się dziać w przyszłości, jest bardzo mocno powiązane z Bożym wyborem i Bożą wiernością owemu wyborowi. Także i w tej apokalipsie Mesjasz staje się obrońcą Żydów przed poganami wyrządzającymi im krzywdę. Jego misja nie ogranicza się jednak tylko do obrony uciśnionych, lecz jest także połączona z sądem. Pomazaniec odbędzie sąd nad narodami. Kryterium tego sądu w wyraźny sposób uzmysławia, jakie jest miejsce Izraela, a jakie narodów w prezentowanej eschatologii. Poganie sądzeni będą bowiem z ich stosunku do Narodu Wy-

${ }^{26}$ Por. K.M. Hogan, Theologies in Conflict in 4 Ezra. Wisdom Debate and Apocalyptic Solution, Leiden 2008, s. 85.

${ }^{27}$ Por. M. Miduch, Apokaliptyka żydowska - o nadziei, Kraków 2012, s. 19-21. 
branego. W tekście księgi czytamy: „każdy naród, który nie panował nad Izraelem ani nie krzywdził pokolenia Jakuba, będzie ocalony" (2 Br 72,4). Żydzi stają się kryterium sądu eschatologicznego, a tym samym zostają wyniesieni ponad inne narody.

Od koncepcji wyraźnie ,izraelocentrycznej” nie odbiega również eschatologia Apokalipsy Abrahama. Tekst apokalipsy zbudowany wokół koncepcji wyboru patriarchy wyraźnie podkreśla miejsce Żydów względem innych narodów. Także i tutaj Mesjasz jest posłany do Izraela, by bronić go przed poganami i pomścić jego krzywdy. Działania eschatologiczne ukierunkowane są tu na wyswobodzenie upodlonego Narodu Wybranego. Zauważalnie mniejszy ładunek emocjonalny w prezentowaniu eschatologii nacjonalistycznej, niż to ma miejsce we wcześniej przywołanych apokalipsach, wcale nie zaprzecza jej wadze. Autor Apokalipsy Abrahama dumny jest ze swego pochodzenia i ufa w Bożą wierność przymierzu, na mocy którego potomkowie patriarchy stali się inni niż narody. Owa inność ściągnęła na Izraela prześladowania, lecz jest także gwarantem Bożej pomocy.

Nietrudno zauważyć, że w trzech przywołanych tu apokalipsach eschatologia nacjonalistyczna odgrywa szczególną rolę. Jest ona środkiem umocnienia tożsamości żydowskiej, którą musiały zachwiać wydarzenia związane z okupacją rzymską. Ciężkie doświadczenia spadające na naród mogły przecież wzbudzić w sercach Żydów wątpliwość co do Bożej wierności przymierzu, które decydowało o tym, że odróżniali się od pogan. Autorzy apokalips stawiają sobie za cel przypomnienie o wybraństwie i wyjątkowej pozycji Żydów w pogańskim świecie. Tożsamość Narodu Wybranego budowana jest w prezentowanych tekstach na zasadzie kontrastu Żyd - poganin. Izrael staje w centrum wydarzeń o charakterze eschatologicznym. Koniec, który się zbliża, nadchodzi ze względu na niego, jego cierpienia są znakiem bliskości wypełnienia obietnic. Narody pogańskie pojawiają się tu wyłącznie jako te, które uciskają Naród Wybrany. Działania Boga są więc skierowane przeciw nim, w obronie Izraela. Takie przedstawienie sytuacji podkreśla wszechobecny $\mathrm{w}$ apokaliptyce dualizm ${ }^{28}$. Naród Wybrany należy tu do sfery dobra, której przeciwstawiony jest świat narodów pogańskich.

\subsection{Eschatologia traumatyczna}

Kolejna koncepcja teologiczna odnosząca się do nadchodzącego końca, wyłoniona $\mathrm{z}$ kart ksiag, to e s c h a to l o g i a tra u maty c zna. Zostało już zasygnalizowane, jak wielki wpływ na prezentowane utwory literackie miała sytuacja polityczna, w jakiej znalazł się Naród Wybrany. Trauma roku 70 odcisnęła swoje

${ }^{28}$ Por. The Interpretor's Dictionary of the Bible, C.R. Crim, G.A. Buttric (ed.), Nashville 1991, s. 133; M. Miduch, Apokaliptyka..., dz. cyt., s. 55-57. 
piętno także na myśli eschatologicznej prezentowanych ksiąg. Doświadczenia będące udziałem Żydów są ciężarem zbyt wielkim, by unieść go ludzkimi siłami. Bezsilność, jakiej doświadczają, znajduje swoje ujście w myśli teologicznej. Naturalne więc jest skierowanie swych nadziei na Boski poziom. Nieszczęścia doświadczane przez Naród Wybrany są motywacją do szukania pomocy u Najwyższego ${ }^{29}$. Ból spowodowany zniszczeniem świątyni owocuje poszukiwaniami teologicznymi wyprowadzonymi poza ramy dotychczasowej teologii, zmusza do poszukiwania nowych ścieżek pocieszenia. Trauma wydarzeń jerozolimskich najbardziej odczuwana jest w IV Księdze Ezdrasza oraz II Księdze Barucha ${ }^{30}$. Wielkie cierpienie jest tu podstawowym elementem tła prezentowanej teologii. Staje się ono punktem wyjścia dla teologicznego dialogu z Bogiem, który ma być źródłem pocieszenia. Każdy z autorów obiera jednak własną drogę poradzenia sobie z przygnębiającą rzeczywistościąi ${ }^{31}$.

Ezdrasz, szanując Prawo i widząc w nim dar Najwyższego dla swojego narodu, dostrzega także ograniczenia mocy owego Prawa wobec nieszczęść spadających na lud. Dar ten postrzega jako niewystarczający na ws półc ze s ne autorowi czasy. Zło, które rozpanoszyło się na świecie, przekracza swoimi rozmiarami wyobrażenia Ezdrasza. Według niego źródło grzechu umiejscowione jest w sercu człowieka, to tu spoczywa korzeń grzechu, czyniąc Prawo bezsilnym ${ }^{32}$. Prawo i grzech istnieją razem i trwa ich odwieczna walka. Nadzieję człowiek może pokładać jedynie w Bogu i Jego miłosierdziu. „Ze względu na nasze grzechy nazywany jesteś miłosiernym" (4 Ezd 8,31) woła w swej modlitwie Ezdrasz. Działanie Boże w czasach ostatecznych wyrażone zostało tu m.in. poprzez figurę Mesjasza, który całkowicie utożsamiony jest z Narodem Wybranym: ,[...] pomazaniec, którego Najwyższy zachował na koniec dni, który powstanie z nasienia Dawida [...]" (por. 4 Ezd 12,32), działa w Bożej mocy i w Bożym autorytecie. Trauma, jakiej doświadczył Naród Wybrany z rąk pogan, wskazuje na kierunek działania Mesjasza. Wystapi on w obronie uciśnionych Żydów, a przeciw narodom, które ich uciskają.

Syryjska Apokalipsa Barucha wobec traumy, jakiej doświadcza naród, koncentruje się na oczekiwaniu nowej pozaziemskiej rzeczywistości. Uwolnienie oczekiwań eschatologicznych z ram materialnych pozwala znaleźć znękanym Żydom miejsce, w którym nie dosięgnie ich prześladowanie wrogów. Chwaleb-

${ }^{29}$ Por. S. Jędrzejewski, Apokaliptyka jako rodzaj literacki, „Ruch Biblijny i Liturgiczny” 51(1998) 1, s. 31.

${ }^{30}$ Por. Pisma ..., dz. cyt., s. 68-69.

${ }^{31}$ Por. The Apocrypha and Pseudoepigrapha of the Old Testament in English, with Introductions and Critical and Explantory Notes, R.H. Charles (ed.), vol. 2, Oxford 1969, s. 553-554.

${ }^{32}$ Problem korzenia grzechu, znajdującego się w ludzkim sercu szerzej rozwija w swoim opracowaniu tematu J. Mazerski. Por. J. Mazerski, Libri IV Esdrae doctrina hamartologica, „Verbum Domini" 13(1933), s. 85-90. 
na rzeczywistość, jakiej oczekują, będzie udziałem Narodu Wybranego. Ucisk, jakiego Izrael teraz doświadcza $\mathrm{z}$ ręki swych pogańskich prześladowców, jest znakiem nadchodzącego końca ziemskiej rzeczywistości. Współegzystencja narodów pogańskich i Izraela owocuje bólem i traumą, z której tylko Bóg może wyprowadzić dobro.

Barucha różni od Ezdrasza podejście do zagadnienia Prawa. W obliczu nieszczęść widzi on w Prawie nadzieję. Sposób, w jaki Bóg wyróżnił Żydów spośród innych narodów, w rzeczywistości eschatologicznej również ma znaczenie: „Ci dla których [...] Prawo było nadzieją [...] dla nich ukażą się cuda w owym czasie" (por. 2 Br 51,7). Żydzi jako jedyni mają ostoję, która może być ich ratunkiem w świecie, który zmierza ku końcowi.

Również w eschatologii Apokalipsy Abrahama odczuwalne jest piętno czasów, w jakich powstała. Mimo iż autor nie opowiada o zburzeniu świątyni w tak przejmujący sposób, jak to czynili Ezdrasz i Baruch, równie dotkliwie odczuwa on dominacje pogan nad Narodem Wybranym. By przekazać swoją teologię, odwołuje się do postaci Mesjasza, którego nazywa „Wybranym”. Widzi w nim mściciela Izraela, który odpłaci narodom za zło, jakie wyrządziły Żydom. Potomstwo Abrahama związane przymierzem ze swoim Bogiem zostanie wybawione z trudnych doświadczeń, jakie są jego udziałem.

IV Księga sybilińska wyróżnia się spośród przywołanych tu apokalips. Inaczej niż IV Księga Ezdrasza, II Księga Barucha czy Apokalipsa Abrahama spogląda w przyszłość. Interwencja Boga wobec szerzącego się w świecie zła zyskuje wymiar warunkowy - zależna jest od kondycji moralnej świata ${ }^{33}$. Co ciekawe, to właśnie Boża interwencja przyjmuje barwy grozy i strachu. Zło panoszące się w świecie, jako że jest udziałem każdego, nie jest traktowane w taki dramatyczny sposób, jak miało to miejsce we wcześniej przywołanych tekstach. Traumatyczny będzie koniec, który nastąpi. Nadejdzie on z woli Bożej i będzie bezpośrednim działaniem Najwyższego w historię ludzką. Sposobem jego uniknięcia, według autora apokalipsy, jest nawrócenie. IV Księga sybilińska nie wyróżnia Izraela, stawia go na równi z innymi narodami w obliczu nadchodzacej zagłady. Poganie nie są w niej elementem opresji, jakiej doświadczają Żydzi. Na równi z nimi są zanurzeni w grzechu i nieprawości świata. Ową równość w Bożej perspektywie podkreślają przywołane tu wydarzenia z historii Narodu Wybranego. Wkomponowane one zostały w wydarzenia historii powszechnej, zburzenie świątyni jest tu ledwo wspomniane, a mieszkańcom Jerozolimy została nadana grecka nazwa „Solimów”34.

Koniec, który powiązany jest z traumatycznymi wydarzeniami, wspólny jest wszystkim czterem apokalipsom, lecz nie wszystkie one rozumieją ową traumę

\footnotetext{
${ }^{33}$ Por. Pisma..., dz. cyt., s. 90.

${ }^{34}$ Sybilla w ten sposób nazywa Żydów, nadając im nazwę od greckiego 'Iєрoбó $\lambda u \mu \alpha$.
} 
jednakowo. Najważniejsza jednak wydaje się w nich głęboka wiara we wszechmoc Boga, do którego należy ostatnie słowo.

\subsection{Eschatologia idylliczna}

Eschatologia idylliczna to kolejna z koncepcji, odnoszących się do rzeczywistości ostatecznej, jaką można spotkać na kartach apokalips powstałych pomiędzy 30-132 rokiem po Chr. Także i tutaj szczególnie mocny akcent został położony na Naród Wybrany. To jego oczyma czytelnik spogląda w stronę nadchodzącego końca. Izrael, który występuje tu w roli uciśnionego i zgnębionego ludu, z nadzieją i radością będzie oczekiwał rzeczywistości, w której objawi się moc Boża. To, co nastąpi po Bożej interwencji, będzie jego udziałem ${ }^{35}$. Mowa tu o chwalebnej i pięknej przyszłości, nie zaś karze i sądzie, które dotkną pogańskie narody.

IV Księga Ezdrasza skupia się głównie na przedstawieniu znaków zbliżającego się końca. Niewiele w niej odniesień do tego, co nastąpi po Bożej interwencji. Autor wspomina jednak o radości i szczęściu w świecie przyszłym, nazywając go ,światem dającym radość” (por. 4 Ezd 7,47). Obraz oczekiwanego świata przyszłego nawiązuje w bezpośredni sposób do obrazu raju. Przywołuje na myśl pierwotną harmonię niezmąconą przez grzech i śmierć: „Dla was bowiem raj został otwarty [...] szczęście zgotowane, miejsce odpoczynku wybrane [...] niemoc wygaszona i śmierć ukryta" (por. 4 Ezd 8,52-54).

Idylliczna rzeczywistość w IV Księdze Ezdrasza łączy się także z postacią Mesjasza. To on gromadzi uciśniony i rozproszony Naród w „granicy świętej” (por. 4 Ezd 13,48), wskazując w ten sposób, komu przeznaczona jest chwalebna przyszłość. Działania mesjańskie wymierzone przeciw narodom są swego rodzaju kontrastem mającym uwypuklić szczęście, jakie jest udziałem Żydów, w obronie których staje Bóg.

II Księga Barucha w ciekawy sposób przedstawia eschatologię idylliczną. Czyni to dwuetapowo. Najpierw prezentuje czytelnikowi ziemskie królestwo mesjańskie, będące pewnym etapem w osiagnięciu niczym niezmąconego szczęścia, trwającego wiecznie. Oba one będą udziałem wyłącznie Żydów. Mesjańskie panowanie cechuje się przede wszystkim czasowością ${ }^{36}$. Znaki, które towarzyszyć będą królowaniu pomazańca, odnoszą czytelników do stworzenia świata, a tym samym do koncepcji raju. Obfitość plonów, urodzaj ziemi, a także uzdrawiająca rosa i manna z nieba to znaki szczególnej Bożej bliskości i troski: ,„...] Także ziemia wyda swoje owoce -1000 z jednego. [...] Duchy zaś wyjdą rankiem sprzed oblicza mego dla przyniesienia w poszczególnych dniach rankiem

\footnotetext{
${ }^{35}$ Por. T. Jelonek, Kultura perska a Biblia, Kraków 2010, s. 166.

${ }^{36}$ Por. P. Bogaert, Apocalypse de Baruch. Introduction, Traduction du syriaque et Commentaire, vol. 1, Paris 1969 , s. 419-420.
} 
zapachu owoców i na końcu dni chmury zsyłające uzdrawiającą rosę [...]. Zstąpi spichlerz manny [...]" (por. 2 Br 29,1-8). Wyzwoleni spod jarzma pogan Żydzi mogą w spokoju zakosztować mesjańskich darów.

Drugi etap idyllicznej eschatologii opisany jest w 44. rozdziale apokalipsy. Bazuje on na kontrastowym zestawieniu tego, co jest, z tym, co będzie ${ }^{37}$. Nadchodząca rzeczywistość zostanie całkowicie pozbawiona zła, śmierci i przemijalności. Także i tu znaleźć można aluzje do raju jako symbolu szczęścia i bliskości Boga. W miejscu tym można zadać pytanie, czy dla autora całkowite unicestwienie zła równa się unicestwieniu narodów pogańskich.

Apokalipsa Abrahama, odwołując się do nadchodzącej rzeczywistości, wspomina o „sprawiedliwym wieku”, który powiązany jest z sądem na tych, którzy prześladują potomstwo Abrahama. Wspomniana została tu także radość ocalonych: „Ukarani przeze mnie bardzo się uradują” (ApAbr 29,19) oraz „Ludzie, którzy unikną zatraty, rozradują się weseląc się bardzo" (ApAbr 31,5), jednak na próżno szukać tu opisów idyllicznej rzeczywistości czekającej Naród Wybrany. Boża sprawiedliwość staje się tu najważniejsza i skierowana zostaje przeciw oprawcom sprawiedliwych.

Podobnie jak w Apokalipsie Abrahama, tak w IV Księdze sybilińskiej niewiele miejsca poświęcono chwalebnej rzeczywistości, która mieściłaby się w ramach eschatologii idyllicznej. Pewne jej elementy odnajdujemy jednak w niezwykle krótkim opisie tego, co czeka wskrzeszonych. Mowa tu o niezniszczalnym bogactwie, darze życia, miłym i rozkosznym blasku słonecznym: „A Ci, którzy są bogobojni, znów żyć będą w świecie Nieśmiertelnego, Wielkiego Boga, w niezniszczalnym bogactwie, gdy Bóg da im tchnienie i życie razem z łaską - im pobożnym. Wszyscy będą dostrzegać samych siebie, spoglądając z podziwem na miłe i rozkoszne światło słoneczne" (4 Syb 189-191). Ci, którym przyjdzie w udziale uczestniczyć w owym życiu, nazwani zostali szczęśliwymi: „O najszczęśliwszy ów człowiek, który żyć będzie na wieki!" (4 Syb 192).

Ucieczka myślami w świat, który nie zna bólu, strachu i przemijalności, jest naturalną reakcją na doświadczenia trudnego okresu, w którym przyszło żyć autorom apokalips. To, czego $\mathrm{z}$ utęsknieniem oczekują, ulokowane zostało w rzeczywistości eschatologicznej. To, co zadaje im ból, znika lub zostaje odsunięte od nich. Nic więc dziwnego, że większość z prezentowanych tekstów w eschatologicznej szczęśliwości nie przewiduje miejsca dla pogan kojarzonych z uciskiem i bólem.

\subsection{Eschatologia nadziei}

Kolejną koncepcją, którą można wyłonić z tekstów apokalips, jest e s c h a tologia nadziei. Historia Narodu Wybranego nauczyła go, że nigdy nie

\footnotetext{
37 Tamże.
} 
został on pozbawiony opieki swojego Stwórcy. Autorzy apokalips pomni na doświadczenia płynące z dziejów ich przodków, właśnie w sposób pełen nadziei patrzą w przyszłość. Nie opierają się oni jednak na własnych siłach i własnych kalkulacjach, ale z ufnością zwracają się ku Bogu. Czyż podobnie los nie doświadczył ich ojców, kiedy zostali uprowadzeni do Babilonii? Czyż świątynia już kiedyś nie została zburzona?

Pełne bólu modlitwy, jakie kieruje Ezdrasz do Najwyższego, są niczym innym jak właśnie wyrazem nadziei, że Bóg czuwa nad swoim ludem, że pozostał wierny swojemu przymierzu. Eschatologiczny koniec, jakiego wypatruje autor, jest $\mathrm{w}$ jego rozumieniu końcem $\mathrm{zła}^{38}$. Nadejdzie on dzięki Bożej interwencji. Oczekiwanie Ezdrasza nie ma w sobie znamion lęku. Działanie Najwyższego będzie przecież miało na celu uratowanie Narodu Wybranego od uciskających go pogan. Bóg jest wierny i pomści krzywdy zadane jego ludowi.

Tak samo jak autor IV Księgi Ezdrasza, Baruch oczekuje z wytęsknieniem dnia, w którym objawi się Boża sprawiedliwość, a wrogowie Izraela otrzymają słuszny, surowy wyrok. Bóg czuwa nad swoim ludem i nie pozwoli, by poganie bezkarnie wyrządzili mu krzywdę. Sąd, który przeprowadzi nad nimi, będzie zadośćuczynieniem temu, co przez długie lata było udziałem Narodu Wybranego. Nadzieja, jaką żywi Baruch, jest bowiem nie tylko nadzieją na życie pozbawione bólu, odbudowanie świątyni, ale także na zapłatę za poniesione krzywdy.

Mimo iż w Apokalipsie Abrahama brak tak wielkiego ładunku emocjonalnego, jaki dostrzec można we wcześniej przywołanych apokalipsach, także jej autor ma nadzieję na odnowienie świata. Wyraz temu daje patriarcha w hymnie, jaki śpiewa, stając przed Najwyższym (por. ApAbr 17,22). Światło jaśniejące nad stworzeniem, o którym wspomniano w hymnie, jest nadzieją nie tylko dla Narodu Wybranego, lecz całego stworzenia. Abraham, spoglądając w przyszłość, widzi, co Bóg przygotował, i jest pewny spełnienia Jego obietnic. Ten jeden przywołany powyżej wers pozwala mieć nadzieję, że autor apokalipsy doświadczenia wiecznej szczęśliwości nie ogranicza tylko do Narodu Wybranego. Być może i poganie będą mieli w niej jakiś udział? Jednak nie wiadomo, czy na równi $\mathrm{z}$ potomkami patriarchy, czy w jakiś inny sposób.

Autor IV Księgi sybilińskiej inaczej patrzy na eschatologiczną Bożą interwencję. Boże działanie wieszczka widzi w kategorii kary, jaka może spaść na świat w wyniku jego zepsucia. Nawrócenie ludzi może powstrzymać straszliwy gniew Boży i nadejście końca. Warto tu wspomnieć, że owo nawrócenie nie zakłada jakiegoś prozelityzmu, przyjęcia Prawa czy też obrzezania, a ma się wyrazić w szczerej wierze w jedynego Boga i odrzuceniu nieprawości. Straszliwy koniec będzie karą za niepodjęcie nawrócenia. Takie podejście do rzeczywistości eschatologicznej wyklucza oczekiwanie na nią. Nie jest ona czasem wyzwolenia dla

\footnotetext{
${ }^{38}$ Por. D.E. Gowan, Eschatology of the Old Testament, Edinburgh 2000, s. 2.
} 
uciśnionych, lecz czasem kary, która spadnie na cały świat - bez rozróżnienia pomiędzy Żydami a poganami.

\subsection{Eschatologia integralna}

IV Księga sybilińska, pod wieloma względami tak różna od powstałych w podobnym okresie apokalips, jako jedyna w swej teologii mocno akcentuje myśl, którą można nazwać e s chatolog i ą in te gralną. Koncepcja ta jest szczególnie cenna dla teologicznego miejsca narodów pogańskich w dziełach żydowskich okresu 70-132 roku po Chr. Sybilla nie czyni różnicy pomiędzy żydami a poganami, wszystkich wzywając do nawrócenia ${ }^{39}$. Każdy człowiek stojący przed Bogiem jest dla autora apokalipsy równy, niezależnie od tego, czy jest on żydem, czy poganinem. Podział ze względu na narodowość czy też wyznawana religię to nie jedyny podział, z jakiego autor apokalipsy rezygnuje: nie rozróżnia on na tych, którzy doświadczą Bożego gniewu, i na tych, którzy zostaną przed nim ocaleni. Model prezentowanej tu eschatologii włącza w swoją koncepcję cały stworzony świat, który jest tu postrzegany jako integralna całość. Równość wszystkiego, co stworzone, podkreśla częste używanie przez autora terminów „cały” i „wszystko”. Jedność świata odpowiada koncepcji jedynego Boga, która jest głównym problemem teologicznym, jaki postanowił zaprezentować autor IV Księgi sybilińskiej.

\section{Od izraelocentryzmu do uniwersalizmu}

Różnorodność, jaką można odnaleźć w starożytnej literaturze żydowskiej, jest odbiciem zróżnicowania, jakie od najdawniejszych czasów było udziałem judaizmu. Wyrażało się ono przede wszystkim w myśli teologicznej. Podobnie jest $\mathrm{w}$ prezentowanych apokalipsach. Zbliżony czas powstania oraz ten sam gatunek literacki dzieł nie wpłynęły jednak na ujednolicenie przesłania teologicznego.

Na tle zróżnicowanych koncepcji odnoszących się do czasów ostatecznych dostrzec można, także zróżnicowane, podejście pogan do tej kwestii. W dwóch pierwszych apokalipsach, tj. IV Księdze Ezdrasza i Syryjskiej Apokalipsie Barucha, patrzymy na świat i jego historię z perspektywy ,izraelocentrycznej”, dwie pozostałe księgi tracą już ową optykę na rzecz coraz to większego uniwersalizmu. IV Księga Ezdrasza w działaniu narodów upatruje znaków niewątpliwie świadczących o nadchodzącym końcu. Podobnie i Baruch widzi w nich przeciwników i wrogów Narodu Wybranego, o niego jednak upomni się Pan i wymierzy poganom zasłużoną karę. Pojawia się tu głębokie przekonanie, że Bóg, wybiera-

\footnotetext{
${ }^{39}$ Por. The Apocrypha..., dz. cyt., s. 396.
} 
jąc swój lud, uczynił go różnym od otaczających go narodów. Apokalipsa Abrahama, jakkolwiek dalej ukazująca potomków patriarchy jako tych, którzy maja szczególne miejsce w planach Boga, nie wyklucza możliwości przyłączenia się do Narodu Wybranego jakiejś liczby pogan. Tym samym otwiera się ona na akceptację możliwości włączenia w obietnice Boże także ludzi pochodzących spoza Izraela.

IV Księga sybilińska natomiast włącza w rzeczywistość eschatologiczną pogan na równi z żydami. Nie dostrzega różnicy pomiędzy Narodem Wybranym a narodami go otaczającymi. Jeden Bóg, którego czcicielem jest Sybilla, odpowiada jednemu, niepodzielonemu światu, który sam stworzył. Świat ten nie ma granic i nikt w nim nie jest wyróżniony.

Niewątpliwie duży wpływ na relację do narodów pogańskich, jaką prezentują omawiane teksty, miało miejsce powstania owych pism. IV Księga Ezdrasza, II Ksiega Barucha są bowiem najmocniej związane z judaizmem jerozolimskim - skupionym wokół kultu świątynnego. Apokalipsa Abrahama, jakkolwiek swoimi korzeniami sięga do judaizmu palestyńskiego, oddala się od centrum kultu ${ }^{40}$. IV Księga sybilińska nosi na sobie wyraźne znamię diaspory. Sama koncepcja sięgnięcia po pogańską wyrocznię, by uczynić z niej narzędzie do nawrócenia ku Jedynemu Bogu, świadczyć może o dużej niezależności owego nurtu judaizmu. Zarówno rozproszenie wśród pogan, wspólne życie codzienne, jak i pewne osłabienie radykalizmu, z którym mamy do czynienia wśród Żydów diaspory, staja się doskonałym tłem dla zarzucenia koncepcji wyboru na rzecz uniwersalizmu. Oryginalny język powstania księgi, tj. język grecki wzorowany na grece homeryckiej ${ }^{41}$, jasno określa środowisko odbiorców tekstu. Żydowski autor dzieła wykazuje troskę o pogan, pragnąc wskazać im jedynego Boga.

Wrogowie, oprawcy, narzędzie zła, które przeciwstawia się odwiecznym zamiarom Boga, to eschatologiczny obraz wyłaniający się z IV Księgi Ezdrasza, II Księgi Barucha oraz Apokalipsy Abrahama. Nie jest on jednak kompletnym odwzorowaniem poglądów judaizmu tego okresu na kwestię pogan. Nie można przecież przemilczeć myśli diaspory. W czasie, kiedy Jerozolima traci na znaczeniu i z każdym rokiem przybywa Żydów żyjących w rozproszeniu, głos Sybilli staje się niezwykle ważny. Jest on głosem reprezentującym ten nurt judaizmu, który już niedługo stanie się dominujący. Niedługo bowiem wszyscy Żydzi znajdą się w diasporze, otoczeni poganami. Spojrzenie na wszystkie narody ziemi jako na równe sobie, tak samo grzeszne, tak samo potrzebujące nawrócenia, stało się droga, jaką obrała Sybilla, by nakłonić świat pogański ku jedynemu Bogu. Owa równość nie zanika w czasach eschatologicznych, trwa nawet w momencie

\footnotetext{
${ }^{40}$ Por. Apokryfy Starego Testamentu, R. Rubinkiewicz (red.), Warszawa 1999, s. 444.

${ }^{41} \mathrm{O}$ stylu homeryckim świadczą używane w tekście księgi końcówki deklinacyjne, charakte-

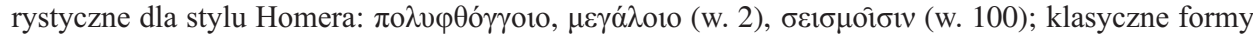

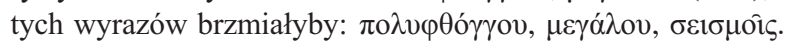


zniszczenia świata przez rozgniewanego Boga. Obietnica szczęścia po wskrzeszeniu nie łączy się tu przecież w żaden sposób z narodowością czy nawet wyznawaną religią - zależy od sprawiedliwości i odwrócenia się od pogańskich bożków. Tym, który spełnia owe warunki, może być przecież zarówno Żyd, jak i człowiek pochodzący z narodów, który rozpoznał prawdę w głosie Sybilli.

\section{The Place of Pagan Nations in the Eschatological Reality of Jewish Apocalyptic Literature in the Period between 70 A.D. and 132 A.D.}

\section{Summary}

Jewish apocalyptic literature appeared in the period between the destruction of the Temple in Jerusalem and the outbreak of the Bar Kokhba Revolt and bears the marks of the difficult times of the Roman occupation, and the persecution which the chosen people suffered at this time. The theological ideas presented in the texts of the four apocalypses illustrate the diversity of Judaism of the period. The expectations of the authors of these texts regarding the future are so varied that one can identify five basic eschatological concepts which are described here as 'nationalistic eschatology', 'traumatic eschatology', 'eschatology of hope', 'idyllic eschatology', and 'universal eschatology'. In these eschatological models different importance is attached to the pagan nations surrounding the people of Israel. The role which they play in eschatological visions is largely conditioned by the circumstances under which these particular texts were created.

\section{Keywords}

apocalyptic literature, apocrypha, eschatology, pagan nations

\section{Słowa kluczowe}

apokaliptyka, eschatologia, apokryfy, narody pogańskie

\section{Bibliografia}

Apokryfy Starego Testamentu, red. R. Rubinkiewicz, Warszawa 1999.

Barlett J.R., Jews in the Hellenistic World, Josephus, Aristeas, The Sibylline Oracles, Eupolemus, Cambridge 1985.

Bogaert P., Apocalypse de Baruch. Introduction, Traduction du syriaque et Commentaire, vol. 1, Paris 1969.

Box G.H.M., Sanday W., The Ezra-apocalypse, London 1912.

Collins J.J., The Sibylline Oracles, w: M. Stone (red.), Jewish Writings of Second Temple Period, Assen-Philadelphia 1984, s. 357-381.

Collins J.J., The Palce of the Fourth Sybil in the Development of Jewish Sibyllina, ,Journal of Jewish Studies" 25(1974), s. 365-380.

Gowan D.E., Eschatology of the Old Testament, Edinburgh 2000.

Hogan K.M., Theologies in Conflict in 4 Ezra. Wisdom Debate and Apocalyptic Solution, Leiden 2008. 
Humphrey E.M., Ladies and the Cities, Transformation and Apocalyptic Identity in Joseph and Aseneth, 4 Ezra, The Apocalypse and Shepherd of Hermas, Sheffield 1995.

Jelonek T., Kultura perska a Biblia, Kraków 2010.

Jędrzejewski S., Apokaliptyka jako rodzaj literacki, „Ruch Biblijny i Liturgiczny” 51 (1998), s. 29-35.

Jędrzejewski S., U korzeni zła, Lublin 1997.

Jędrzejewski S., Angelologia Etiopskiej Księgi Henocha (Henet), „Ruch Biblijny i Liturgiczny" 3(2006), s. 203-218.

L'apocalypse d'Abraham, en vieux slave, introduction, texte critique, tradition et commentaire, red. R. Rubinkiewicz, Lublin 1987.

Liber Apocalypseos Baruch Filii Neriae, translatus de greco in syriacum et Epistola Baruch Filii Neriae, red. M. Kmosko, Paris 1907

Mazerski J., Libri IV Esdrae doctrina hamartologica, „Verbum Domini” 13(1933), s. 84-90.

Mędala S., Wprowadzenie do literatury międzytestamentalnej, Kraków 1994.

Miduch M., Apokaliptyka żydowska - o nadziei, Kraków 2012, s. 19-21.

Nickelsburg G.W.E., Jewish Literature between the Bible and the Mishna, Minneapolis 2005.

Oracula Sibillina, red. C. Alexandre, Paris 1869.

Parchem M., Księga Daniela, Częstochowa 2008.

Pilarczyk K., Literatura żydowska od epoki biblijnej do haskali. Wprowadzenie religioznawcze, literackie i historyczne, Kraków 2006.

Pisma apokaliptyczne i testamenty, red. M. Parchem, Kraków 2010.

Rivka N., The Destruction of Jerusalem and the Idea of Redemption in Siriac Apocalypse of Baruch, Leiden-Boston 2003.

Rubenstein A., Hebraisms in the Apocalypse of Abraham, „Journal of Jewish Studies, 2(1954), s. 132-135.

Rubinkiewicz R., Apokalipsa Abrahama 1-6. Propozycje interpretacji symbolicznej, „Roczniki Teologiczno-Kanoniczne” 29, 1(1982), s. 69-79.

Sacchi P., L'apocalittica giudaica e la sua storia, Brescia 1999.

Text and Studies, Contribution to Biblical and Patristic Literature, vol. 7, red. J. Armitagr Robinson, Cambridge 1895.

The Apocalypse of Abraham (with a translation from the Slovanic text and notes), G.M.H. Box (red.), London 1919.

The Apocrypha and Pseudoepigrapha of the Old Testament in English, with Introductions and Critical and Explantory Notes, R.H. Charles (ed.), vol. 2, Oxford 1969.

The Apocrypha and Pseudoepigrapha of the Old Testament, vol. 2, R.H. Charles (ed.), Oxford 1969.

The Apocryphal Old Testament, H.F.D. Sparks (ed.), Oxford 1984.

The Interpretor's Dictionary of the Bible, C.R. Crim, G.A. Buttric (red.), Nashville 1991.

VanderKam J.C., Wprowadzenie do wczesnego judazimu, Warszawa 2006.

Witczyk H., Narodziny $i$ dzieje państwa $w$ dawnym Izraelu, w: Życie społeczne $w$ Biblii, G. Witaszek (red.), Lublin 1997.

Wright J.E., Baruch Ben Neriah. From Biblical Scribe to the Apocalyptic Seer, South Carolina 2003. 